\title{
Effectiveness of Food Sustainability Education among Grade School Students
}

\author{
Loran Luehr ${ }^{\mathrm{a}}$ and Dr. Sylvia Smith ${ }^{\mathrm{a}}$
}

Increasingly, the human population is having an impact on the environment. Educating younger generations on sustainability issues may make a difference. The goal of this project was to raise awareness and change attitudes toward food sustainability issues by creating an effective educational program targeted to elementary ( $4^{\text {th }}$ grade) and junior high $\left(6^{\text {th }}\right.$ and $8^{\text {th }}$ grade) age students. The project was a four-week interactive program focusing on local foods, gardening, recycling, and world hunger. Participants included 47 elementary students and 38 junior high students from two local grade schools in southern Illinois. To determine the program effectiveness, a within-subjects, repeated measures design was utilized to compare mean scores of participants. Pre and post-program surveys were analyzed to measure the effectiveness of the program. The level of significance was established at $\mathrm{p}<0.05$. Results indicated that the program was most effective with fourth and eighth grade students. Fourth grade students had significant changes in awareness of world hunger and Community Supported Agriculture (CSA). Eighth grade students had significant changes in awareness of CSA and what they eat effecting the world around them. Sixth grade students had significantly higher mean scores in awareness of CSA. Positive results in each age group suggest that interactive food sustainability programs introduced at elementary and junior high age groups may prove effective. Future sustainability projects should focus on finding additional hands-on techniques to increase student awareness of food and the environment.

Keywords: Food, Sustainability, Local Foods

\section{Introduction}

Humans are continuing to have a negative impact on natural resources and the environment. An understanding of sustainable practices could improve the current situation (Harmon \& Maretzki, 2006). Sustainability has been described as practices that meet the needs of the present without compromising future generations to meet their own needs. It is further defined in terms of economic and social justice by establishing fundamental framework of ecology, economy and equity (ADA Sustainability Primer, 2007). Sustainability can be divided into several important categories, one of which is food sustainability. Food sustainability affecting everyone (Maslow's Hierarchy of Needs) focuses heavily on agriculture, ecology, economics and social studies (Harmon \& Maretzki, 2006).

Current changes in the US farming industry have resulted in a reduced number of farms, from 6.4 million farms in 1910 to 2.2 million farms in 1997 (Lyson, 2004). Smaller, individually owned farms have been unable to compete with large corporate farms that are dominant today (Izuma, Alaimo, \& Hamm, 2010). These large farms, despite their efficiency, must use an immense amount of nonrenewable resources to transport products to various locations (Hamm \& Bellows, 2003). This scenario is not only costing the environment and risking our food security for the future (Hamm \& Bellows, 2003), but also producing products that lack quality (Izuma, 2010). Elementary and junior high students do not have an understanding of the current food sustainability crisis (Harmon \& Maretzki, 2006), and yet, they are the primary solution to correcting the problem (Wilkins, 2009). By educating younger generations about the production, distribution, and consumption of our current food system, they can make educated choices to change this trend and strengthen our local food supplies for the future (Harmon \& Maretzki, 2006).
To address the food sustainability crisis, an interactive four-week program based on local food sustainability education was created and implemented in two grade schools in southern Illinois. The program goal was to increase awareness and change attitudes toward food sustainability issues targeting fourth, sixth, and eighth grade students in hopes of developing a program that can be incorporated into school curriculums in the future. The research questions included:

1) How are student attitudes and awareness toward local food sustainability affected by a food sustainability educational program?

2) How effective is a local food sustainability program at the fourth, sixth, and eighth grade levels?

\section{Experimental Procedures}

Permission was given to teach a local food sustainability program to fourth, sixth, and eighth grade students at two schools in southern Illinois. The fourth grade class consisted of 47 participants, sixth grade had 19 participants, and the eighth grade class included 19 participants (see Table 1). The fourth grade class was part of an elementary school environment. The sixth and eighth grade classes were in a junior high environment. The four-week educational program was created using ideas from the Girl Scouts of America "Sow What?" journey book (Person, Naomi \& Takahama, 2009), in addition to creative ideas from the primary researcher. Each week included a hands-on, one-hour session focusing on a different topic. The topics included local foods, gardening, recycling, and world hunger. Each topic consisted of an interactive activity and taste testing session. Pre and post-surveys were given before and after the program, respectively, to measure attitudes and awareness of participants in regards to food sustainability specifically targeting locally grown foods. Surveys focused on 
knowledge of world hunger, community supported agriculture (CSA), and behaviors associated with farmers' markets and local foods. Stages of change theory was used to help guide the research (Prochaska, 2001). Stages of change is a model categorizing individuals within a level of change based on his or her motivation to modify behavior. The model monitors progress through five stages. These stages are precontemplation, uninformed or uninterested; contemplation, intention to change but ambivalent; preparation, intention to change with a plan; action, changes are made; maintenance, ongoing work to maintain the change (Prochaska, 2001). An example of one of the stages of change questions used in the study was "Are you and your family trying to eat locally grown foods?" Responses included "no" (precontemplation), "yes, we're going to start eating locally grown foods in the next 6 months" (contemplation), "yes, we're going to start eating locally grown foods in the next 30 days" (preparation), "yes, we have been eating locally grown foods for less than 6 months" (action), and "yes, we have been eating locally grown foods for more than 6 months" (maintenance).

In addition to the stages of change questions, other questions were asked regarding awareness and attitudes of local food sustainability. Yes/No questions were asked of participants referring to their awareness of local foods. Examples of local food awareness questions included, "Have you ever been to a Farmer's Market?" and "Do you care where your food is grown?" Response to yes/no questions were calculated as "yes" equals 1 while "no" equals 0 . Means were taken of the participants' pre and post survey answers to the questions. Additionally, questions concerning local food sustainability attitudes were presented to the participants. Attitude questions were measured on a likerttype agreement scale where $0=$ strongly disagree and $4=$ strongly agree. Examples of attitude questions included, "I am interested in knowing what foods I eat are grown in Illinois" and "I wish stores would carry more food that is produced locally." Attitude questions were derived from previous research regarding food sustainability (Harmon, 2006).

To determine the program effectiveness, a withinsubjects, repeated measures design was utilized to compare mean scores of participants from the pre and post surveys.
PASW (Version 18.0) was used to analyze the data. The level of significance was set at $\mathrm{p}<0.05$.

\section{Results}

\section{Demographic Results}

Table 1 presents the demographic characteristics of the elementary and junior high student sample. In terms of gender, $55 \%$ of the participants were female, while $45 \%$ were male. The ethnic composition of the participants was similar to the current U.S. population with $70 \%$ Caucasian, $10 \%$ African American, 6\% Asian/Pacific Islander, yet only 2.5\% Hispanic. Because of the large amount of participants within the fourth grade class, the majority of participants, $55.3 \%$, were between the ages of 8 and 10 years old. The 11 to 12 age group and the 13 to 14 age group each represented $22.3 \%$ of the participants, respectively.

\section{Stages of Change Theory}

The survey contained two stages of change questions. These questions were "Are you and your family trying to eat locally grown foods?" and "Would you and your family like to participate in CSA?" Although neither stages of change question produced significant results in any of the grade levels, there was progression from the precomtemplative stage to the contemplative stage in all age groups for both questions (see Tables 8, 9, and 10). Continuing this study as a longitudinal study would help determine whether significant stages of change movement could be made.

\section{Program Assessment}

An assessment of the overall program was made in the post survey, and results indicated that $89 \%$ of all students, regardless of age, tasted a food they had never tried before. These foods included horseradish sauce, whole-wheat banana bread, homemade granola, garden-fresh strawberry jam, butternut squash, pure baked pumpkin, and oatmeal raisin cookies. The assessment also found that when all students were asked if they enjoyed the overall program and were given the choices of "yes", "somewhat", or "no", 97\% answered "yes", $3 \%$ answered "somewhat", and $0 \%$ answered "no".

Table 1: Demographic Characteristics of the Sample

\begin{tabular}{|c|c|c|c|c|c|}
\hline Variable & $\begin{array}{c}\text { Trico 4th Grade } \\
(n=47)\end{array}$ & $\begin{array}{c}\text { U.P. 6th Grade } \\
(n=19)\end{array}$ & $\begin{array}{c}\text { U.P. 8th Grade } \\
(n=19)\end{array}$ & Total $(n=85)$ & $\%$ Frequencies \\
\hline \multicolumn{6}{|l|}{ Gender* } \\
\hline Male & 23 & 5 & 10 & 38 & $45.24 \%$ \\
\hline Female & 24 & 13 & 9 & 46 & $54.76 \%$ \\
\hline \multicolumn{6}{|l|}{ Race* } \\
\hline White/Caucasian & 37 & 10 & 11 & 58 & $70.73 \%$ \\
\hline African American & 2 & 2 & 4 & 8 & $9.76 \%$ \\
\hline American Indian & 3 & 0 & 0 & 3 & $3.66 \%$ \\
\hline Asian/Pacific Islander & 0 & 4 & 1 & 5 & $6.10 \%$ \\
\hline Hispanic & 1 & 0 & 1 & 2 & $2.44 \%$ \\
\hline Other & 1 & 3 & 1 & 5 & $6.10 \%$ \\
\hline \multicolumn{6}{|l|}{ Age } \\
\hline $8-10$ & 47 & 0 & 0 & 47 & $55.30 \%$ \\
\hline $11-12$ & 0 & 19 & 0 & 19 & $22.36 \%$ \\
\hline $13-14$ & 0 & 0 & 19 & 19 & $22.36 \%$ \\
\hline
\end{tabular}

*Totals are less than 85 because of unreported data 
Table 2: $4^{\text {th }}$ Grade Results for Awareness of Food Issues

\begin{tabular}{|c|c|c|c|}
\hline (2) & Pre-Survey Mean & Post-Survey Mean & Sig. (2-tailed) \\
\hline $\begin{array}{l}\text { Have you ever been to a Farmer's } \\
\text { Market? }\end{array}$ & 0.91 & 0.72 & 0.352 \\
\hline $\begin{array}{l}\text { Do you care where your food is } \\
\text { grown? }\end{array}$ & 0.47 & 0.60 & 0.219 \\
\hline $\begin{array}{l}\text { Do you know what world hunger } \\
\text { is? }\end{array}$ & 0.74 & 0.98 & $0.001 *$ \\
\hline $\begin{array}{l}\text { Do you think what you eat effects } \\
\text { the world around you? }\end{array}$ & 0.53 & 0.72 & 0.056 \\
\hline $\begin{array}{l}\text { Do you know what Community } \\
\text { Supported Agriculture (CSA) is? }\end{array}$ & 0.17 & 0.72 & $0.001 *$ \\
\hline
\end{tabular}

$*$ indicates significant positive change $(\mathrm{p}<0.05)$

Table 3: $4^{\text {th }}$ Grade Results on Attitudes of Local Food Sustainability

\begin{tabular}{|c|c|c|c|}
\hline & $\begin{array}{l}\text { Pre-Survey } \\
\text { Mean }\end{array}$ & $\begin{array}{l}\text { Post-Survey } \\
\text { Mean }\end{array}$ & $\begin{array}{c}\text { Sig. } \\
\text { (2-tailed) }\end{array}$ \\
\hline I am interested in knowing what foods I eat are grown in Illinois & 2.81 & 3.11 & 0.110 \\
\hline $\begin{array}{l}\text { I'm not concerned whether the food I eat comes from nearby or } \\
\text { far away }\end{array}$ & 2.64 & 2.26 & 0.127 \\
\hline I would enjoy growing my own food & 3.32 & 3.34 & 0.913 \\
\hline I wish stores would carry more food that is produced locally & 2.78 & 3.13 & 0.092 \\
\hline $\begin{array}{l}\text { I wish my school cafeteria would serve some foods grown by } \\
\text { local farmers }\end{array}$ & 3.13 & 2.96 & 0.414 \\
\hline
\end{tabular}

*indicates significant positive change $(\mathrm{p}<0.05)$

Participants utilized a five-point likert scale to indicate their level of agreement: $0=$ strongly disagree to $4=$ strongly agree.

Table 4: $6^{\text {th }}$ Grade Results for Awareness of Food Issues

\begin{tabular}{|c|c|c|c|}
\hline 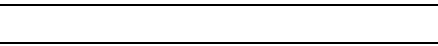 & Pre-Survey Mean & Post-Survey Mean & Sig. (2-tailed) \\
\hline $\begin{array}{l}\text { Have you ever been to a Farmer's } \\
\text { Market? }\end{array}$ & 0.89 & 0.95 & 0.533 \\
\hline $\begin{array}{l}\text { Do you care where your food is } \\
\text { grown? }\end{array}$ & 0.72 & 0.74 & 0.923 \\
\hline $\begin{array}{l}\text { Do you know what world hunger } \\
\text { is? }\end{array}$ & 0.88 & 1.00 & 0.163 \\
\hline $\begin{array}{l}\text { Do you think what you eat effects } \\
\text { the world around you? }\end{array}$ & 0.56 & 0.74 & 0.262 \\
\hline $\begin{array}{l}\text { Do you know what Community } \\
\text { Supported Agriculture (CSA) is? }\end{array}$ & 0.28 & 0.74 & $0.004 *$ \\
\hline
\end{tabular}

*indicates significant positive change $(\mathrm{p}<0.05)$

Table 5: $6^{\text {th }}$ Grade Results on Attitudes of Local Food Sustainability

\begin{tabular}{|c|c|c|c|}
\hline & $\begin{array}{l}\text { Pre-Survey } \\
\text { Mean }\end{array}$ & $\begin{array}{c}\text { Post-Survey } \\
\text { Mean }\end{array}$ & Sig. (2-tailed) \\
\hline I am interested in knowing what foods I eat are grown in Illinois & 2.72 & 3.11 & 0.216 \\
\hline $\begin{array}{l}\text { I'm not concerned whether the food I eat comes from nearby or } \\
\text { far away }\end{array}$ & 2.33 & 1.84 & 0.201 \\
\hline I would enjoy growing my own food & 2.82 & 2.79 & 0.924 \\
\hline I wish stores would carry more food that is produced locally & 2.72 & 3.00 & 0.379 \\
\hline $\begin{array}{l}\text { I wish my school cafeteria would serve some foods grown by } \\
\text { local farmers }\end{array}$ & 2.50 & 2.79 & 0.448 \\
\hline
\end{tabular}

*indicates significant positive change $(\mathrm{p}<0.05)$

Participants utilized a five-point likert scale to indicate their level of agreement: $0=$ strongly disagree to $4=$ strongly agree. 
Table 6: $8^{\text {th }}$ Grade Results for Awareness of Food Issues

\begin{tabular}{|c|c|c|c|}
\hline & Pre-Survey Mean & Post-Survey Mean & Sig. (2-tailed) \\
\hline $\begin{array}{l}\text { Have you ever been to a Farmer's } \\
\text { Market? }\end{array}$ & 0.90 & 0.84 & 0.570 \\
\hline $\begin{array}{l}\text { Do you care where your food is } \\
\text { grown? }\end{array}$ & 0.71 & 0.68 & 0.840 \\
\hline $\begin{array}{l}\text { Do you know what world hunger } \\
\text { is? }\end{array}$ & 1.00 & 1.00 & 1.000 \\
\hline $\begin{array}{l}\text { Do you think what you eat effects } \\
\text { the world around you? }\end{array}$ & 0.48 & 0.79 & $0.040 *$ \\
\hline $\begin{array}{l}\text { Do you know what Community } \\
\text { Supported Agriculture (CSA) is? }\end{array}$ & 0.14 & 0.95 & $0.001 *$ \\
\hline
\end{tabular}

*indicates significant positive change $(\mathrm{p}<0.05)$

Table 7: $8^{\text {th }}$ Grade Results on Attitudes of Local Food Sustainability

\begin{tabular}{|c|c|c|c|}
\hline & $\begin{array}{l}\text { Pre-Survey } \\
\text { Mean }\end{array}$ & $\begin{array}{l}\text { Post-Survey } \\
\text { Mean }\end{array}$ & $\begin{array}{c}\text { Sig. } \\
\text { (2-tailed) }\end{array}$ \\
\hline I am interested in knowing what foods I eat are grown in Illinois & 2.52 & 2.52 & 0.99 \\
\hline $\begin{array}{l}\text { I'm not concerned whether the food I eat comes from nearby or } \\
\text { far away }\end{array}$ & 2.10 & 1.90 & 0.56 \\
\hline I would enjoy growing my own food & 2.24 & 2.47 & 0.50 \\
\hline I wish stores would carry more food that is produced locally & 2.81 & 2.58 & 0.46 \\
\hline $\begin{array}{l}\text { I wish my school cafeteria would serve some foods grown by } \\
\text { local farmers }\end{array}$ & 2.70 & 3.00 & 0.35 \\
\hline
\end{tabular}

*indicates significant positive change $(\mathrm{p}<0.05)$

Participants utilized a five-point likert scale to indicate their level of agreement: $0=$ strongly disagree to $4=$ strongly agree.

Table 8: 4th Grade, Stages of Change Question Frequencies

\begin{tabular}{|c|c|c|c|c|c|c|c|c|c|c|c|}
\hline & \multicolumn{2}{|c|}{ No } & \multicolumn{2}{|c|}{$\begin{array}{l}\text { Yes, next } 6 \\
\text { months }\end{array}$} & \multicolumn{2}{|c|}{ Yes, next 30 days } & \multicolumn{2}{|c|}{$\begin{array}{l}\text { Yes, have been less } \\
\text { than } 6 \text { months }\end{array}$} & \multicolumn{2}{|c|}{$\begin{array}{l}\text { Yes, have been } \\
\text { more than } 6 \\
\text { months }\end{array}$} & \multirow[t]{2}{*}{$\begin{array}{c}\text { Sig. } \\
\text { (t-tailed) }\end{array}$} \\
\hline & Pre & Post & Pre & Post & Pre & Post & Pre & Post & Pre & Post & \\
\hline $\begin{array}{l}\text { Are you and your } \\
\text { family trying to } \\
\text { eat locally grown } \\
\text { foods? }\end{array}$ & 23 & 23 & 4 & 4 & 4 & 4 & 3 & 5 & 13 & 10 & 0.787 \\
\hline $\begin{array}{l}\text { Would you and } \\
\text { your family like to } \\
\text { participate in } \\
\text { CSA? }\end{array}$ & 36 & 26 & 3 & 6 & 5 & 11 & 1 & 1 & 2 & 2 & $\begin{array}{c}0.159 \\
(0.159)\end{array}$ \\
\hline
\end{tabular}

Table 9: 6th Grade, Stages of Change Question Frequencies

\begin{tabular}{|c|c|c|c|c|c|c|c|c|c|c|c|}
\hline & \multicolumn{2}{|c|}{ No } & \multicolumn{2}{|c|}{$\begin{array}{l}\text { Yes, next } 6 \\
\text { months }\end{array}$} & \multicolumn{2}{|c|}{$\begin{array}{l}\text { Yes, next } 30 \\
\text { days }\end{array}$} & \multicolumn{2}{|c|}{$\begin{array}{l}\text { Yes, have been less } \\
\text { than } 6 \text { months }\end{array}$} & \multicolumn{2}{|c|}{$\begin{array}{l}\text { Yes, have been more } \\
\text { than } 6 \text { months }\end{array}$} & \multirow{2}{*}{$\begin{array}{c}\text { Sig. } \\
\text { (t-tailed }\end{array}$} \\
\hline & Pre & Post & Pre & Post & Pre & Post & Pre & Post & Pre & Post & \\
\hline $\begin{array}{l}\text { Are you and your } \\
\text { family trying to eat } \\
\text { locally grown foods? }\end{array}$ & 9 & 6 & 1 & 5 & 1 & 0 & 1 & 3 & 11 & 10 & 0.954 \\
\hline $\begin{array}{l}\text { Would you and your } \\
\text { family like to } \\
\text { participate in CSA? }\end{array}$ & 16 & 13 & 6 & 11 & 0 & 0 & 0 & 0 & 0 & 0 & $\begin{array}{l}0.201 \\
(.199) \\
\end{array}$ \\
\hline
\end{tabular}


Table 10: 8th Grade, Stages of Change Question Frequencies

\begin{tabular}{|c|c|c|c|c|c|c|c|c|c|c|c|}
\hline & \multicolumn{2}{|c|}{ No } & \multicolumn{2}{|c|}{$\begin{array}{c}\text { Yes, next } 6 \\
\text { months }\end{array}$} & \multicolumn{2}{|c|}{$\begin{array}{c}\text { Yes, next } 30 \\
\text { days }\end{array}$} & \multicolumn{2}{|c|}{$\begin{array}{c}\text { Yes, have been } \\
\text { less than } 6 \\
\text { months }\end{array}$} & \multicolumn{2}{|c|}{$\begin{array}{c}\text { Yes, have been } \\
\text { more than } 6 \\
\text { months }\end{array}$} & \multirow[t]{2}{*}{$\begin{array}{c}\text { Sig. } \\
\text { (t-tailed }\end{array}$} \\
\hline & Pre & Post & Pre & Post & Pre & Post & Pre & Post & Pre & Post & \\
\hline $\begin{array}{l}\text { Are you and your family } \\
\text { trying to eat locally grown } \\
\text { foods? }\end{array}$ & 13 & 11 & 1 & 5 & 1 & 0 & 0 & 1 & 10 & 6 & 0.66 \\
\hline $\begin{array}{l}\text { Would you and your family } \\
\text { like to participate in CSA? }\end{array}$ & 21 & 17 & 3 & 2 & 1 & 2 & 0 & 0 & 0 & 1 & $\begin{array}{c}0.271 \\
(0.293) \\
\end{array}$ \\
\hline
\end{tabular}

\section{Discussion}

The current design of the program allowed for a lecturebased learning experience with hands-on components. The survey instrument was pilot tested in a college class at a local university. Overall, the program produced interesting results. The program was found to be effective, even at low levels of success, suggesting that food sustainability introduced through interactive programs may be effective at influencing awareness of target ages. Future research should determine program activities for varying age groups.

The receptiveness of the fourth grade students during class sessions seemed much higher than that of the sixth and eighth grade classes. This may be attributed to a more relaxed setting at the elementary school in comparison to junior high school. The fourth grade students willingly participated in activities and were eager to learn each new topic. The eighth grade students, on the other hand, were not as willing to participate, but still received the same effectiveness score as the fourth grade students.

To answer research question 2, the program was effective because there were significant changes found in each age group. The program needs to be improved, however, in order to increase the amount of changes found within the varying grade levels. The lack of change and negative changes in regards to the remaining questions should be assessed to determine why the program did not affect these specific topic areas. There were nine questions that produced negative results, six of which were attitude questions and three were awareness questions. The questions that produced these results should be reexamined and retested to determine if the questions were worded in such a way that was not understood by students or whether the length of the survey caused the students to lose interest and not give attentive answers. Students may have not have given their fullattentionto the post survey since it was the final component of the program before their lunch break. Had the surveys been given at the start of a new class period, the results may have been different.

The educational program had interactive components that did seem to increase students' engagement and comprehension. A previous study on school gardens indicated that hands-on gardening education was more effective at teaching sixth grade students than one without the interactive component (McAleese, 2007). Although this sustainability project had interactive components including a garden craft, local foods taste testing, world hunger demonstration, and recycling relay, the question as to whether there was enough interaction must be addressed. Alongside each interactive activity was a PowerPoint lecture. Future programs may incorporate a classroom discussion, in addition to a lecture, to help increase student interest and engagement in the topic. Future projects could focus on finding more hands-on techniques and delivery, such as school gardening, composting, or cooking to increase student engagement especially among sixth grade students.

When analyzing data, all students experienced significantly higher mean scores in CSA. Was it such new material the students were more engaged? Overall, students regardless of age did enjoy the program. A food sustainable education class can be an exciting beneficial addition to the school curriculum. Changes need to be made to make it more effective at varying ages. Today's students are the solution for tomorrow's sustainable future, and a food sustainability education program is one step toward that goal.

\section{Limitations}

This project is limited by factors of sample size, demographics, and the exploratory nature of the research. The sample sized used was a small sample size of only 85 students. The age, ethnicity, and gender of the population were not generalizable. Both schools involved were located in rural southern Illinois. A study repeated in an urban or suburban area may produce vastly different results. This research was an exploratory research project that was not based on a previous research program. The project was based on original ideas of the researcher and the Girl Scouts of America "Sow What?" journey book (Person, Naomi, and Takahama, 2009). To create a more reliable study, the program should be repeated for longitudinal results with a similar population and program design.

\section{Acknowledgments}

The Southern Illinois University Carbondale Research Enriched Academic Challenge made this project possible through financial funding. Trico Elementary School and Unity Point School worked with the researchers to assist in the program. Dr. Sylvia Smith acted as research advisor for this project and helped in many aspects of it. 


\section{References}

American Dietetic Association Sustainable Food System Task Force. Healthy Land, Healthy People: Building a Better Understanding of Sustainable Food Systems for Food and Nutrition Professionals. A Primer on Sustainable Food Systems and Emerging Roles for Food and Nutrition Professionals. Chicago, IL: American Dietetic Association; 2007.

Beets, M. W., Swanger, K., Wilcox, D. R., \& Cardinal, B. J. (2007). Using hands-on demonstrations to promote cooking behaviors with young adolescents: the culinary camp summer cooking program. Journal of Nutrition Education Behavior. 30, 288-289. doi: 10.1016/).jneb.2007.05.002.

Hamm, M. W., \& Bellows, A. C. (2003). Community food security and nutrition educators. Society for Nutrition Education, 35, 37-43. doi: 10.1016/S14994046(06)60325-4.

Harmon, A. H. (2006). A Survey of Food System Knowledge, Attitudes, and Experiences Among High School Students. Journal of Hunger and Environmental Nutrition, 1, 59-82.

Harmon, A. \& Maretzki, A. N. (2006). Assessing food system attitudes among youth: development and evaluation of attitude measures. Journal of Nutrition Education Behavior, 38, 91-95. doi: 10.1016/j.jneb.2005.11.029.

Izumi, B. T., Alaimo, K., \& Hamm, M. W. (2010). Farm-toschool programs: perspectives of school food service professionals. Journal of Nutrition Education Behavior, 42, 83-91. doi: 10.1016/j.jneb.2008.09.003.
Lyson, Thomas A. (2005). Civic Agriculture: Reconnection Farm, Food, and Community. Medford, MA: Tufts University Press.

McAleese, J., and L. Rankin. "Garden-Based Nutrition Education Affects Fruit and Vegetable Consumption in Sixth-Grade Adolescents." Journal of the American Dietetic Association 107.4 (2007): 662-65. Print.

Person, Naomi \& Takahama, V. (2009). How to Partner with Girl Scout Seniors on Sow What?: It's Your PlanetLove It!. New York: Girl Scouts of the USA, 2009. Print. Prochaska, James O., and John C. Norcross (2001). "Stages of Change." Psychotherapy: Theory, Research, Practice, Training 38.4: 443-48.

Walters, L. M. \& Stacey, J.E. (2009). Focus on food: development of the cooking with kids experiential nutrition education curriculum. Journal of Nutrition Education, 41, 371-373. doi: 10.1016/j.jneb.2009.01.004.

Wilkins, Jennifer L. (2009). Civic dietetics: opportunities for integrating civic agriculture concepts into dietetic practice. Agriculture Hum Values, 26, 57-66. doi: 10.1007/s10460-008-9177-2.

Zepeda, Lydia. (2009). Which little piggy goes to market? Characteristics of US farmers' market shoppers. International Journal of Consumer Studies, 33, 250-257. doi: 10.1111/j.1470-6431.2009.00771.x. 